\title{
A Detour in the Local Turn: Roadblocks in Timor-Leste's Post-Conflict Peacebuilding
}

\author{
Dahlia Simangan
}

Liberal missteps have paved the way for the local turn in post-conflict peacebuilding. However, localized peacebuilding does not always produce peaceful outcomes. Several scholars have previously demonstrated that unresolved tensions from international-local encounters result in a negative hybrid peace in which political and social hierarchies are preserved and conflict and violence persist. To add to existing analyses on the local turn in peacebuilding, this article analyzes some of the causes and consequences of negative hybrid peace using the case of Timor-Leste. Exclusive and superficial local involvement, political cleavages within the local leadership, and unresolved tensions from international-local encounters were roadblocks in TimorLeste's post-conflict peacebuilding. These characteristics prelude a return to a status quo dominated by the local elite and plagued with governance and socio-economic issues.

Keywords peacebuilding, local involvement, hybrid peace, Timor-Leste, United Nations

\section{Introduction}

Liberal principles shape the conduct of international peacebuilding (Joshi, Lee, and Mac Ginty 2014), and the return of violence in some post-conflict societies has been attributed to the limits of liberal peacebuilding (Heathershaw 2008; Lidén 2009; Cooper, Turner, and Pugh 2011; Selby 2013). Critiques of liberal peace and its exportation to post-conflict societies have paved the way for a local turn in peacebuilding (Mac Ginty 2008; Newman, Paris, and Richmond 2009; Richmond 2009). At the forefront of this trajectory is the concept of hybrid peace. Hybrid peace scholars magnify the gap between local realities and the kind of peace being generated for the local population, and scrutinize the interactions between the liberal and the local (Richmond 2010; Mac Ginty 2010a; Mac Ginty and Richmond 2015). Hybrid forms of peacebuilding, however, do not always produce peaceful outcomes. Mac Ginty and Richmond differentiate between 
positive and negative hybrid peace (Mac Ginty 2010a; Mac Ginty and Richmond 2015; Richmond 2015). Positive hybrid peace is achieved when socio-political injustices are addressed in a contextually rooted process, while negative hybrid peace preserves oppressive and violent structures (Richmond 2015).

This article seeks to explore the characteristics, causes, and consequences of negative hybrid peace using the case of Timor-Leste, and to identify the types of local involvement that deter rather than promote lasting peace in post-conflict societies. Much has been written about the outcomes of liberal peacebuilding in Timor-Leste (Richmond and Franks 2008; Hughes 2009; Lemay-Hébert 2011; Braithwaite 2012; Wallis 2012) and several scholars have already raised caution over the consequences of superficial local involvement in artificial institutions of liberal peace (Richmond 2011b; Wallis 2012; Randazzo 2016; Simangan 2017). This article contributes to the growing discussion on the local turn in peacebuilding by substantiating the concept of negative hybrid peace. While the concept of hybrid peace is receiving increasing attention in scholarship and policymaking, there is limited discussion that differentiates between forms of hybrid peace. Using the concept of negative hybrid peace as an analytical lens recognizes the role of local actors and agency and departs from the focus on the negative aspects of liberal peacebuilding, which has already been highlighted in previous scholarships and debates. This article also has the benefit of retrospection through including more recent events in Timor-Leste, considering that peacebuilding outcomes continue to evolve even after an international mission concludes. To illustrate this, Timor-Leste has been called a miracle nation, a failed state, and a success story at different stages of its post-conflict peacebuilding process (Bexley and Nygaard-Christensen 2014; see also, Asahi 2017).

Timor-Leste is an excellent case study for this assessment because of the United Nation's (UN) unprecedented governing mandates, which have set an enduring standard for international peacebuilding. The UN's mandates in TimorLeste mirror the assumptions of liberal peacebuilding, and the implementation of its mandates epitomizes the complex dynamics between international and local actors. The data for analysis was drawn from scholarly assessments, official reports, and personal interviews. These interviews were part of broader fieldwork conducted from late 2013 to early 2014 when the author interviewed UN officials, local leaders, and members of civil society organizations who were involved in various components of peacebuilding in Timor-Leste. ${ }^{1}$ While acknowledging that the local has more than territorial attachments and encompasses activities and agencies (Mac Ginty 2015, 830), this article focuses on local actors, alongside their actions and decisions, who were directly or indirectly involved in the peacebuilding process.

The first part of this article will provide a conceptual scoping of hybrid peace. It will be followed by a brief background on Timor-Leste's transition to 
peace and UN efforts towards a localized peacebuilding process. It will then discuss the roadblocks that made the local turn in peacebuilding take a detour in Timor-Leste. Instead of a positive form of hybrid peace, exclusive and superficial involvement of the fragmented local, compounded by unresolved tensions from international-local encounters (causes of negative hybrid peace), inhibited rather than nurtured the emancipatory potential of local agency and allowed the preservation of elite interests in an oppressive status quo (characteristics of negative hybrid peace). This contributed to a negative hybrid peace characterized by political dominance and corruption, unstable security, and poor governance (consequences of negative hybrid peace).

\section{Negative Hybrid Peace}

Liberal peace in transitional contexts gained prominence and legitimacy in the 1990s after the Cold War when communist and authoritarian states transitioned to liberal democracy and sought open forms of economic policies (UN 1992). The assumption is that liberal democratic institutions and market-oriented policies can successfully sustain peace and development (Doyle 1983; Keohane and Nye 1989; Russett 1996). As the dominant framework for peace operations championed by international actors, primarily western liberal states, liberal peacebuilding has become the "universal blueprint" of intervening actors (Richmond and Franks 2009, 140). However, incidents of relapse to conflict and reversal to authoritarianism in post-conflict societies have challenged the effectiveness and legitimacy of the liberal peacebuilding framework.

While defenders of liberal peacebuilding recommend a better implementation of liberal peace (for example, Paris 2010), critics highlight the liberal agenda's detachment from local aspirations to peace. The top-down, exclusionary, and Western-based tendencies of liberal peace create a kind of peace that is alienating and non-emancipatory for local societies (Richmond 2006; Andrieu 2010; Mitchell 2010). The local turn in peacebuilding purportedly aims to address the failures of liberal assumptions in building inclusive and lasting peace in postconflict societies. ${ }^{2}$ The local turn magnifies the gap between the realities and aspirations of the local population and the kind of peace being generated for them, which in turn creates local resistance (Richmond 2010; Mac Ginty 2010a; Mac Ginty and Richmond 2015). This resistance, and other kinds of encounters between locals and internationals, consequently produces hybrid peace. Mac Ginty (2010a) defines hybrid peace as a product of processes of accommodation, cooperation, compromise, and encounters between agents, networks, and structures of peace and peacemaking. It incorporates the agency and power of local actors where exogenous and indigenous factors come together in a common pursuit of peace (ibid.). These hybrid forms of peace can only advance beyond 
liberal peace, however, if they have emancipatory and empathetic characteristics (Richmond 2015).

One of the strengths of the concept of hybrid peace is that it highlights the "locally rooted, everyday needs, behaviours, and aspirations" of a post-conflict society by reassessing the impact of actors, networks, and structures on the achievement of peace (Belloni 2012, 33-34). Mac Ginty (2010b) emphasizes the utility of the concept in excavating the underlying structural factors that have caused the violence and conflict, which liberal peace tends to ignore or, sometimes unintentionally, intensify. Richmond (2011a, 15) also demonstrates that the concept of hybrid peace allows an examination of the everyday forms of peace or those that are "culturally appropriate form [s] of individual or community life and care." In her extensive ethnographic analysis of conflict zones, Autesserre (2014) confirms that these everyday forms of peace significantly impact the effectiveness of peacebuilding efforts.

Hybrid forms of peacebuilding, however, do not always produce peaceful outcomes. Several scholars have pointed out cases (for example, Jarstad and Olsson 2012; Raeymaekers 2013; Philipsen 2014; Wallis, Jeffery, and Kent 2016) when hybrid institutions and processes are conflict-promoting and exclusionary (Millar 2014; Nadarajah and Rampton 2015) or reproducing elements of the status quo instead of creating a liberal transformation (Barnett, Fang, and Zürcher 2014). Hybrid peace can be either positive or negative (Mac Ginty 2010a; Mac Ginty and Richmond 2015; Richmond 2015). A positive hybrid peace, according to Richmond (2015, 51-63), reflects contextually rooted processes in which social and political injustices are addressed across international and local levels. It strikes a balance between international preferences and localized power structures, but remains located in the everyday. Most importantly, it is empathetic and emancipatory because it adopts approaches that are ultimately defined by its subjects rather than external actors. In contrast, a negative hybrid peace has oppressive social, political, or military structures in which elite interests and the status quo are preserved (ibid., 51-64). It is born out of a failure to address tensions arising from liberal-local encounters, and as a result international and local actors, norms, and interests remain opposed. Negative hybrid peace rests on hybrid politics in which structural violence is maintained and liberal norms are undermined. It is instrumentalized, artificial, hegemonic, and one-sided, being either too internationalized or too localized (Mac Ginty and Richmond 2015, 230). Instead of bringing local empowerment and emancipation, a negative hybrid peace process simply outsources power and norms from the international to the local (Richmond 2015, 51).

Encounters between international and local actors and norms are not always equal and their asymmetrical relationships may re/produce forms of power. Björkdahl and Höglund (2013) identify six possible responses to these frictional encounters. First is compliance or forced adherence or submission to 
international norms and practices. Second is the adoption of international norms and practices at the local level. Third is the adaptation or contextualization of international norms and practices to local characteristics. Fourth is co-option or strategic adoption of international norms into the local as a means of averting pressure. Fifth is resistance or the dominance of local characteristics alongside the limited adoption of international norms and practices. Sixth is rejection or exclusion of international norms and practices from the local.

Mac Ginty (2010a; 2011) describes four constantly changing variables in a hybrid peace process. First is liberal peace assertiveness in which "promoters of liberal peace are able to mobilize a formidable suite of compliance mechanisms to encourage conformity and to discipline attempts at deviance" (Mac Ginty 2010a, 398). Second is liberal peace incentives or the rewards or benefits that come from compliance with liberal peace. Third is the ability of local actors to resist, subvert, negotiate with, and ignore the liberal peace, which shows that local actors and agencies are non-passive and autonomous. Fourth is the ability of local actors to create alternatives to liberal peace that are rooted in the local context instead of importing liberal peace models. Björkdahl and Höglund's categories and Mac Ginty's conceptual model are useful for identifying the roadblocks in TimorLeste's peacebuilding.

\section{Contextual Background}

The case of Timor-Leste is a milestone in the liberal peacebuilding agenda because of the unprecedented scope and depth of UN activities on the ground and the substantial engagement of local actors (Suhrke 2001; Richmond and Franks 2008). After an Australian-led multinational taskforce intervened in the violent aftermath of a referendum that ended the twenty-four year Indonesian occupation, the UN Security Council (UNSC) passed Resolution 1272 establishing the United Nations Transitional Administration in East Timor (UNTAET). It was mandated from October 1999 to May 2002 to administer Timor-Leste while preparing it for independence. It was tasked to "provide security and maintain law and order throughout the territory of Timor-Leste; establish an effective administration; assist in the development of civil and social services; ensure the coordination and delivery of humanitarian assistance, rehabilitation, and development assistance; support capacity-building for selfgovernment; and assist in the establishment of conditions for sustainable development" (UNSC 1999, 2-3).

Resolution 1272 also stipulated "the need for UNTAET to consult and cooperate closely with the East Timorese people in order to carry out its mandate effectively with a view to the development of local democratic institutions, including an independent East Timorese human rights institution, and the 
transfer to these institutions of its administrative and public service functions" (UNSC 1999, para. 8). By mid-2000, UNTAET had started the "Timorization" of the transitional government by incorporating local counterparts into governing structures to increase local participation. To provide governing experience for the local leadership, the East Timor Transitional Administration (ETTA), which was composed of five Timorese ministers and four international staff members, replaced the Governance and Public Administration (GPA) pillar of UNTAET. The GPA was previously mandated to re-establish governance at the central and district levels, generate public and social utilities, establish the rule of law, and encourage and regulate private investments. In addition, the National Council (NC) replaced the National Consultative Council (NCC) to reflect the increased Timorese membership. The councils were the primary mechanisms for representing the Timorese people to UNTAET (UNTAET 1999; 2000b). These new mechanisms were established to provide local actors with more governance responsibilities. An elected Constituent Assembly was tasked with writing a new constitution which was passed on March 22, 2001 as the new Constitution of the Democratic Republic of Timor-Leste. The presidential election was held on April 14 of the same year, and Xanana Gusmão, a high-profile resistance leader, won a landslide victory. On May 20, Timor-Leste became an independent nation and the UN handed the administration to the newly elected president and, for the first time after years of occupation, to the Timorese people.

The UN Mission in Support of East Timor (UNMISET) succeeded UNTAET and was mandated to provide assistance to core administrative structures, to provide interim law enforcement and assist in the development of new law agency enforcement in Timor-Leste, and to contribute to the maintenance of TimorLeste's overall security (UNSC 2002; 2003; 2004a; 2004b). It concluded in May 2005 and was immediately succeeded by a small political mission, the UN Office in Timor-Leste (UNOTIL), which was tasked with overseeing the consolidation of state institutions until May 2006 (UNSC 2005a). One month before the conclusion of UNOTIL's mission, a security crisis erupted in Dili when military protests turned violent, resulting in the collapse of security institutions. While this article acknowledges that several other factors, which were independent of the international intervention, contributed to the crisis proving unstable security in Timor-Leste, it was also a consequence of exclusive and superficial involvement by the fragmented local and unresolved tensions arising from international-local encounters. The UN Independent Special Commission of Inquiry for TimorLeste $(2006,74)$, which investigated the crisis, concluded that:

The violent events of April and May [2006] were more than a series of criminal acts. They were the expression of deep-rooted problems inherent in fragile State institutions and a weak rule of law. The events exposed many deficiencies and failures, particularly in the two institutions at the centre of the crisis, F-FDTL [the East Timor 
Defence Force or Falintil-Forças de Defesa de Timor Leste] and PNTL [the East Timor Police Force or Polícia Nacional de Timor-Leste], along with the Ministry of Defence and the Ministry of the Interior [that were in charge of] their oversight. The absence of comprehensive regulatory frameworks and the bypassing of existing institutional mechanisms, even if underdeveloped, contributed significantly to the emergence and growth of the crisis.

Thirty-eight were killed, sixty-nine were wounded, and more than 150,000 were displaced in the aftermath of the crisis (ibid.). The UNSC extended UNOTIL's mission for another month in light of the situation (UNSC 2006a). In response to the Timorese government's request for assistance in controlling the spreading violence, an Australian-led International Stabilisation Force (ISF) arrived on May 25, 2006. Three months later, the UNSC authorized the deployment of the UN Integrated Mission in Timor-Leste (UNMIT), also in response to the Timorese government's request. Its overarching mandate was to address the political, humanitarian, and security crisis in Timor-Leste, and to enhance stability, democratic governance, and political dialogue (UNSC 2006b). In November 2012, the ISF commenced the withdrawal of its forces from TimorLeste and UNMIT completed its mission in December 2012.

\section{Roadblocks in Timor-Leste's Post-Conflict Peacebuilding}

The UN missions in Timor-Leste were able to build liberal institutions of governance. Learning from its past experiences, and in response to criticisms of its predominantly top-down approach in previous missions, the UN tried to tweak its shortcomings by expanding its mandates and involving more local actors. Compared to previous UN transitional administrations, UNTAET included more local involvement by assigning Timorese to branches and levels of the transitional government. However, these hybrid processes failed to build an inclusive and lasting peace, partly because of the exclusive and superficial involvement of the fragmented local and unresolved tensions arising from international-local encounters.

\section{Exclusive and Superficial Local Involvement}

UNTAET faced dilemmas in fulfilling its extraordinarily unprecedented task of building peace in a post-conflict emergency context while promoting the liberal values of democracy and good governance. For example, lengthy consultations with local counterparts may slow down programs that require quick decisionmaking processes. On the other hand, sidelining local involvement in decisionmaking processes may undermine the international administration's legitimacy (Hohe 2002; Lemay-Hébert 2009a). In recognizing the challenge of exercising and 
bringing about democracy in a post-conflict society, the Special Representative of the Secretary-General (SRSG) in Timor-Leste, Sergio Vieira de Mello, said that UNTAET's task was to develop "a model for good governance through benevolent despotism" (Beauvais 2000-2001, 1114-1115). However, at the outset of its mission, UNTAET failed to strike a balance between its administrative role and transitional nature.

Local elites expressed discontent over UNTAET's authority and centralized power across peacebuilding components. They felt marginalized in a peacebuilding process they had fought for and perceived UNTAET as the new ruler that replaced Indonesia. Gusmão vented this sentiment when he said, "we have no power, no legitimacy to do anything. I do not want to cause friction but we do not feel comfortable with some people acting like kings of East Timor, coming here to impose their models" (Norling 1999). With legislative and executive powers solely in the hands of the SRSG, the local population felt disenfranchised in the political process and building of institutions (Pushkina and Maier 2012, 337). "The UN is not a democratic body; how do you expect it to create democratic institutions," said Charles Scheiner, founder of and researcher at La'o Hamutuk, an NGO working for social and economic justice in TimorLeste since 2000 (personal communication, February 24, 2014). He observed that UNTAET focused more on its role as an administrator by governing Timor-Leste and overlooked the transitional context of its mandate of preparing the country for self-governance.

Segments of the local civil society also perceived UNTAET as an authoritarian body with centralized decision-making power and narrow allowance for genuine local involvement. UNTAET, specifically the GPA, was seen to be Dili-centric and detached from the plight of those who lived in the districts (Smith and Dee 2003; Nixon 2012). The emergency context during the early phase of UNTAET in Timor-Leste did not allow opportunities for immediate local involvement that was inclusive of all other sectors of society. While this is understandable, UNTAET's initial disengagement harbored frustration among members of civil society. According to an international staff member who worked in the Human Rights Unit of UNTAET, mechanisms for local consultation were absent, resulting in resentment from members of local civil society who felt that UNTAET was not interested in seeking their opinions (personal communication, October 31, 2013). The local NGOs that were working with her relayed their negative perception of UNTAET, specifically regarding how the UN leadership was not interested in the sentiments and views of the local population. For example, other sectors of society, such as women, youth, and traditional leaders, were not represented in the NCC, which was filled with self-appointed political elites (Strating 2016, 86).

Local involvement during the transition was exclusive to the local elite, particularly those who were prominent leaders during the resistance. As one former UNTAET human rights officer said, "the UN was very messy when they 
first came in terms of local engagement; they did not know who to talk to and very quickly they got surrounded by a particular group who was quite clever at keeping people out" (personal communication, March 5, 2014). This led to the creation, or at least affirmation, of a political elite, and the exclusion of individuals and groups who were not part of it. This exclusive local involvement was mainly manifested in the composition of the Constituent Assembly (UNTAET 2001b). Although the members of the Assembly were democratically elected, the Revolutionary Front for an Independent East Timor or Frente Revolucionária de Timor-Leste Independente (Fretilin) dominated its composition, since it was the largest and most influential political party at that time. Wallis (2013, 135-136) argues that Fretilin's dominance in constitution-making allowed for a historical narrative favorable only to Fretilin while disenfranchising other security groups, such as the clandestine resistance movement composed of younger Timorese. ${ }^{3}$ This exclusive participation in the constitution-making process instigated regional divisions among local actors that fueled the 2006 security crisis (Wallis 2014,318 ) and silenced the contribution of other legitimate groups to TimorLeste's peacebuilding process.

This exclusionary result was manifested in the Disarmament, Demobilization, and Reintegration (DDR) process. The internationals provided compliance mechanisms, although limited and delayed, for former combatants to go through the DDR process. However, there were reports of selection bias in that some of the commanders of the Armed Forces for the National Liberation of East Timor or Forças Armadas de Libertação Nacional de Timor-Leste (Falintil), the armed wing of Fretilin, were deliberately excluded from the list of reintegration assistance beneficiaries (Mc Carthy 2002; IOM 2011-2012). The DDR process was not designed to accommodate all former combatants and the dissatisfaction of those who were excluded from the process invoked their participation in the 2006 security crisis. In particular, martial arts groups (MAGs) were active in the clandestine front in support of the resistance movement, but were disenfranchised during the establishment of new security forces mobilized to participate in the 2006 violence. ${ }^{4}$ The failure of the Timorese leadership to manage Timorese society's high expectations coming from independence was one of the driving factors in the crisis. ${ }^{5}$

Even the involvement of the local elite was not without criticism. For one, because of the short time frame of UNTAET's mission, there was no room to reflect on the outcomes of the consultations with ETTA and NC, according to Sue Ingram, a district administrator under UNTAET (personal communication, October 23, 2013). An UNTAET human rights officer also pointed out the lack of streamlined policies on how local consultation should be done, resulting in inconsistent outcomes. For example, the Timorese had active roles in terms of writing and passing legislation, but not in other aspects of security, justice and reconciliation, and economic development (personal communication, March 5, 
2014). There were also gaps and misunderstandings between UNTAET and the Timorese leadership in terms of peacebuilding priorities (ETTA minister and Fretilin member, personal communication, February 20, 2014).

Another common reflection by those the author interviewed was that the involvement of local actors, particularly of the Timorese leadership, occurred only on the surface. UNTAET equated local involvement with information dissemination or telling the locals what was being done, instead of giving them more active roles. A Timorese who advocates for the democratization of Timor-Leste's institutions commented that the implementation of Timorization was far from what was planned. In practice, the Timorese had less substantial powers compared to their international counterparts (personal communication, November 30, 2013). He was referring to the implementation of an UNTAET regulation that stipulated the establishment of local administrative structures and appointment of local counterparts in village and sub-district levels for development activities (UNTAET 2000a). There was no structure within UNTAET that allowed the Timorese to participate in the decision-making process (Suhrke 2001), and the lengthy negotiations and political compromises on power-sharing arrangements between international agencies and local leadership diluted the role of the Timorese in the administration (Chopra 2000a).

\section{Fragmented Local}

Exclusive and superficial local involvement raises a question about the representativeness of the locals who were involved. Pushkina and Maier (2012, 339) noted that UNTAET delegated responsibilities to some bureaucrats and former guerilla members who were not qualified and unable to communicate with the rest of the population. For example, the local elite was composed of older, Portuguese-speaking expatriates whose interests and priorities were detached from the majority of the Timorese population, who lived during the Indonesian occupation and therefore mainly spoke Bahasa, the Indonesian language (Della-Giacoma 2000). Moreover, UNTAET initiated the Timorization process without sufficient awareness and readiness to face the reality that the local elite was fragmented by political factionalism (Cummins 2015, 34). This lack of local understanding was rife within UNTAET, such that there was an assumption that the mission was working in a political vacuum despite the fact that members of the resistance movement had already gained political clout and public support during the Indonesian occupation (Ingram, personal communication, October 23, 2013; see also Chopra 2002, 998). UNTAET's continual involvement of the local elite disenfranchised other groups and contributed to, rather than mediate, the increasing opposition between factions.

The first sign of this factionalism was between the lorosae, or those coming from eastern districts, and loroтunu, or those coming from western districts. Although this division has no socio-political authenticity, especially outside Dili, 
the affiliations to either lorosa'e or loromunu were manipulated and exaggerated to back up the political confrontations during the 2006 security crisis (Hicks 2009, 93). When Gusmão gave a speech in March 2006 and called the dismissal of some of F-FDTL members unjust, he attributed the problem to the lorosae-loromunu divide within the F-FDTL. The prejudiced distinction between the two was the assertion by the lorosae that the loromunu did not contribute as much as they did to the resistance (Simonsen 2009, 578). Prior to the crisis, the 159 F-FDTL soldiers who sent a petition citing discrimination against them within the F-FDTL were loromunu. It was a common view among the loromunu that the lorosae had taken over the good houses in Dili during the crisis, and houses owned by lorosae were burnt down (ibid.).

Another taciturn element of factionalism that was especially scratched open during the 2006 security crisis was the political cleavage within the Timorese leadership, specifically between Gusmão and Mari Alkatiri. Gusmão is the charismatic guerrilla leader of the Falintil and has been known as the "Mandela of the East" since his capture in 1992 and imprisonment in Indonesia until 1999. Alkatiri was the leader and one of the founding members of Fretilin who was exiled in Mozambique during the Indonesian occupation. Shoesmith $(2003,235)$ has explained that the root of this political cleavage is an ideological difference that goes back to the 1974-1975 period when Fretilin established control over Portuguese Timor, declared independence from Portugal, and waged a war of resistance against the Indonesian invasion. Alkatiri belongs to the radical left and Gusmão belongs to the more moderate center. In December 1987, Gusmão withdrew from Fretilin and declared Falintil's neutrality in fighting for national independence and political freedom instead of holding to any political ideology (Niner 2001).

In April 1986, Gusmão established the National Council of Maubere Resistance or Conselho Nacional da Resistência Maubere (CNRM), an umbrella organization which developed into the National Council of Timorese Resistance or Conselho Nacional de Resistência Timorense (CNRT) with a nonpartisan nationalist strategy, and was elected as its president. According to Shoesmith (2003), during the first year of UNTAET's administration, attempts to work out the differences between Gusmão and Alkatiri/Fretilin under the CNRT movement failed due to unresolved practical issues of governance and the deep-seated animosity between the two. For Alkatiri, Fretilin was the true representative of the Timorese people and the single major party that should retain control of the government. Gusmão, on the other hand, repudiated Fretilin's privileged status over other political parties and reasoned for a multiparty democracy. In August 2000, Fretilin withdrew from the CNRT and campaigned independently for the Constituent Assembly elections. Although Fretilin bested the other fifteen parties that contested the elections, it fell short of obtaining a two-thirds majority. Meanwhile, the CNRT lost political clout but 
Gusmão succeeded in his objective of removing Fretilin's control over Falintil (ibid., 241). Moreover, Gusmão's charismatic leadership from the period of resistance until the transition to independence cemented his position in TimorLeste's politics and society. Gusmão demanded discipline, especially from the Falintil members who faithfully obeyed his command, and led the negotiations with the Indonesian government and the $\mathrm{UN}$ in determining Timor-Leste's future (Niner 2004).

The political factionalism between Gusmão and Alkatiri spilled over to the rebuilding of security institutions, specifically the selection of members for the new defense and police forces. In January 2001, UNTAET passed a regulation on the establishment of the F-FDTL with the mission of "providing for the military defence of East Timor, its people and its territory; and providing assistance to the civilian community at the request of the civilian authorities during natural disasters and other emergencies" (UNTAET 2001a). UNTAET authorized the F-FDTL High Command, which was composed of former Falintil commanders who were loyal to Gusmão and to former Falintil Commander Taur Matan Ruak, to conduct the recruitment process for the F-FDTL. As a result, the appointments and selections were often partial and politicized instead of expertise- and experience-based (Hood 2006, 63; see also Sukma 2002). The first battalion was composed of Gusmão loyalists and dominated by lorosaee (Ingram 2012, 11). A sizable minority of those who were left out in the recruitment felt disgruntled and spiteful towards Gusmão and the F-FDTL High Command, and leaned towards Fretilin (Rees 2004, 49).

Seven months after the establishment of the F-FDTL, UNTAET passed a regulation in August 2001 on the establishment of the PNTL with the main purpose of maintaining law and order within the country (UNTAET 2001c). Similarly to how it partnered with Falintil commanders in the selection of F-FDTL officers, UNTAET limited its consultation to a select group of CNRT members with regard to the composition of the PNTL (Hood 2006). Moreover, the delayed deployment of UN Civilian Police (CivPol) officers and the pressure from key UN member states to withdraw the international security forces as soon as possible prompted an expedited process for the recruitment and training of local police officers. Although this was done in order to immediately hand over policing responsibility to the Timorese, such hasty decision-making did not provide adequate time for background checks and training (Goldstone 2012). This had a major impact on the composition and quality of the PNTL, which added to the discontent among disenfranchised security groups.

Some police officers who were recruited were previously part of the Indonesian police-an unacceptable decision for Timorese who had suffered from brutality and human rights violations committed by Indonesian officers and for resistance members who had fought for independence. The selection of former Indonesian National Police (POLRI) officers was justified on the basis of 
their experience and familiarity with policing duties, ${ }^{6}$ even though their skills were questionable given their lowly ranks in the POLRI (Hood 2006, 53). Former POLRI officers had shorter training periods compared to the new cadets. Instead of the regular three-month training, which in itself was too short to adequately prepare police officers, they only underwent four weeks of training (ibid.).

Disgruntled ex-combatants that were disenfranchised in the establishment of the F-FDTL and PNTL organized themselves into several "political security groups" that challenged the legitimacy of the newly established security institutions (Scambary 2009, 269). They were connected under the umbrella Association of Ex-Combatants 1975 (AC75) headed by Rogerio Lobato, another prominent Fretilin member (ibid.). Lobato was also appointed as the Minister of Interior in 2002 and therefore was in control of the PNTL. These groups expressed anti-UN and anti-F-FDTL sentiments (Rees 2004, 50) and participated in the violence in and rampaging through Dili during the 2006 security crisis (Scambary 2009, 274). Lobato, an ally of Alkatiri, transformed the PNTL into a highly militarized institution to compete with the Gusmão-influenced F-FDTL (Lemay-Hébert 2009b, 395). The UN Independent Special Commission of Inquiry for Timor-Leste $(2006,51)$ found Lobato guilty of unlawful movement, possession, and use of PNTL weapons to illegally arm civilians during the crisis. F-FDTL commander Matan Ruak and Minister of Defense Roque Rodrigues were also found guilty of having knowledge of and giving approval to unlawful movement, possession, and use of weapons. The Commission also concluded that there was reasonable suspicion that Alkatiri had knowledge of the distribution of PNTL weapons to civilians.

The formation of the F-FDTL and PNTL had striking contrasts. The lack of consolidation of the two security forces was evident in the way their formation was planned and implemented. First, the development of the F-FDTL was delayed by political considerations; the creation of the PNTL was slowed more by administrative and logistical setbacks. Second, UNTAET treated the transfer of security responsibilities differently for the F-FDTL and PNTL. It was flexible and tolerant when transferring from the UN Peacekeeping Force to the F-FDTL, but constrained and pressing when transferring from CivPol to the PNTL (Goldstone 2012). Third, while the F-FDTL was mainly composed of former Falintil members, the PNTL had some police officers who served during the Indonesian occupation. Fourth, the F-FDTL was loyal to Gusmão while the PNTL was loyal to Alkatiri. The uneasy marriage of the differences between the F-FDTL and PNTL, aggravated by their internal socio-political cleavages, did not sit well in the newly established security institutions.

\section{Unresolved Tensions Arising from International-Local Encounters}

The encounters between international and local actors and agencies during the peacebuilding process inevitably produced tensions. These tensions were mainly 
rooted in differing priorities between UNTAET and the Timorese leadership. The first of these was state-building versus nation-building, which may have been a result of UNTAET's mandate. Beauvais notes that "the most striking characteristic of [UNTAET's] mandate [was] its fundamental duality, which although conceptually compatible was practically problematic: to act as the de facto government while preparing Timor-Leste for democratic self-government" (Beauvais 2000-2001, 1108; see also Suhrke 2001). UNTAET's two-year tenure was too short to deliver components of its mandate that required a long-term commitment, such as capacity-building for self-government and establishing conditions for sustainable development. The initial emergency phase occupied UNTAET with tasks related to security and humanitarian assistance. Only later in the mission did UNTAET focus on institution-building to work itself out of the job. On the other hand, the Timorese leadership emphasized the need for national unity, civil society, and the promotion of liberal democratic values given its colonial history and fight for independence (Timor-Leste's government official, personal communication, February 28, 2014). Both Gusmão and José RamosHorta, the Nobel Peace Prize-winning spokesman of the Timorese resistance, expressed the need for Timor-Leste to embrace national unity and democratic values (Ramos-Horta 1999, 119; Murdoch 2000).

The UN missions in Timor-Leste were able to rebuild the institutions necessary for self-governance during the transition. However, according to the majority of the interview participants, UNTAET focused more on rebuilding institutions than on developing the mechanisms for these institutions to deliver their responsibilities. Not only did the short time frame of UNTAET not allow for sufficient capacity-building, it also left little room for error. Antonio Vitor, a youth leader during the transition, described the implication of this: "what capacity can you build in two years? It was too short and if you do not do it properly, you do not solve the problem but rather you become part of the problem" (personal communication, February 20, 2014). For Hugo Fernandes, a Commission for Reception, Truth and Reconciliation (CAVR) official, TimorLeste is still in the process of transition because, while the physical instruments of governance have been established, "they do not have a soul; they are empty" (personal communication, March 6, 2014). As Richmond and Franks $(2008,197)$ put it, "the state has taken on the external appearance of a liberal polity without the necessary internal developments."

This tension between institution-building and the promotion of liberal values was also apparent in Timor-Leste's transitional justice, but it was not confined within international-local encounters. Instead, it came out from the difference between the local elite's political priorities and the broader population's fight for justice. Despite strong evidence that the Indonesian military was responsible for the violence surrounding the 1999 referendum, the UN decided not to establish an international tribunal in order to avoid confrontation with Indonesia 
(Bowman 2004, 381). UNTAET established the Special Panels in Timor-Leste to hold accountable the perpetrators of serious crimes and violence. The Panels completed fifty-five trials and tried eighty-seven (eighty-four convicted and three acquitted) mostly low-level defendants (UNSC 2005b). Indonesia also established an ad hoc tribunal in Jakarta to deal with human rights offenses committed by Indonesians in Timor-Leste, but international human rights organizations and civil society groups in Timor-Leste considered the tribunal a joke, a sham, and a show trial to institutionalize the impunity of Indonesian officials (Human Rights Watch 2002; East Timor and Indonesia Action Network 2005).

In 2001, the Comissão de Acolhimento, Verdade e Reconciliação de Timor Leste (CAVR), or the Commission for Reception, Truth and Reconciliation, was created to uncover the truth of human rights violations during the Indonesian occupation, foster community-level reconciliation, and recommend measures to further promote human rights. In the same year, the Timorese and Indonesian governments jointly established the Commission of Truth and Friendship (CTF) to find the truth about human rights violations and institutional responsibility in order to contribute to reconciliation and friendship between Timor-Leste and Indonesia (CTF 2008). However, international organizations and local civil society criticized the creation of the CTF as a political tool for Timor-Leste and Indonesia to ease their relations (Perry 2009, 199) and another way of providing impunity for Indonesian perpetrators (Timor-Leste National Alliance for an International Tribunal 2008). Both the Timorese and Indonesian governments are still yet to fully adopt the recommendations of CAVR and CTF.

Those the author interviewed believe that many of the Timorese still seek justice for the most serious crimes committed during the Indonesian occupation and post-referendum violence. They also maintain that the preference of the political elite to reconcile with Indonesia overshadowed the victims' and their families' right to reparations (see also Stanley 2009; Evans 2012, 202). For the Timorese, reconciliation should come with justice, which is different from the view of some political elites that Timor-Leste should be reconciled with Indonesia regardless of whether it was right or wrong, just or unjust (Fernandes, personal communication, March 6, 2014). To compensate for the lack of justice from liberal institutions that were established during the transition, the local population reverted to indigenous and community-level reconciliation (Hohe 2003).

Another tension between international priorities and local demands came from the DDR process. UNTAET had no explicit mandate included in Resolution 1272 regarding the DDR process for former combatants. Before the referendum, Gusmão ordered Falintil members to remain in cantonment and resist fighting with the Indonesian forces and militia groups. Falintil generally complied with this order and remained in cantonment in the Aileu district in the northwestern part of Timor-Leste even during the post-referendum violence and after the 
arrival of UNTAET. There was hesitation among UN officials to enforce a DDR process for Falintil because it might be seen as a way of providing assistance to an armed rebel group, something that the UN Charter does not permit (Hood 2006, 59). The DDR of Falintil was a sensitive issue for the UN: should Falintil be treated as "an illegal armed group to be disarmed or the nucleus of a defence force?" (Martin and Mayer-Rieckh 2005, 134). Considered the heroic resistance group from which the Timorese leaders came, Falintil expected to keep its role as the de facto army of the country.

Initially, the Timorese leadership vowed not to have its own army (RamosHorta 1999, 120), but the post-referendum violence shifted their stance. The local leadership's determination to have a national army and its recommendation to transform Falintil into a conventional army, rather than completely demobilizing or dismissing it, were later on agreed upon and supported by UNTAET (ETTA minister and Fretilin member, personal communication, March 5, 2014). However, UNTAET's initial indecisiveness over Falintil's status incited discontent among its members. Although Falintil members were allowed to carry arms in the cantonment area (UN CivPol officer, personal communication, October 1, 2013; see also Kingma 2001, 29), worsening conditions drove some of them to move out, thereby raising internal security concerns. While the Australian-led International Force for East Timor (INTERFET) and UNTAET manifested an intention to demilitarize all ex-combatants, UNTAET's focus on external security, specifically from the militia threats along the border with Indonesia, and Falintil's unwillingness to disarm left the DDR process on the periphery of peacebuilding priorities. This tension between international priorities and local demand did not help with fostering local ownership and respect for the rule of law. The delayed and incomplete consolidation of the security sector in Timor-Leste contributed to the violence during the 2006 security crisis.

\section{A Detour in the Local Turn}

Timorization is a hybrid peace process in action. It was UNTAET's response to criticisms that it was not providing sufficient avenues for the Timorese to be involved in the peacebuilding process. It was a step forward in preparing the country for self-government, but it took a detour from the local turn's emancipatory and empathetic potential. Instead of a positive hybrid peace with genuine international-local partnership, the involvement of the local elite in Timor-Leste was mainly based on superficial relations, which is a characteristic of negative hybrid peace (Richmond 2015, 64). Instead of a process that was ultimately defined by the local and rooted in local contexts, the local was involved in processes and mechanisms that were essentially defined by the international. Local involvement in international programs will not automatically result in 
local ownership, especially if these programs are exported by the international administration and the sense of ownership is judged by local elites (Richmond 2012, 371). It is, therefore, unsurprising that the UNTAET-led Timorization received criticism (Chopra 2000b; Chesterman 2002) for parading as a process moving towards local empowerment and ownership while in reality the local counterparts had only consultative roles under the heavy-handed supervision of their international counterparts. Moreover, the exclusive involvement of the local elite in Timor-Leste helped to preserve a status quo that disenfranchised those at the margins of Timorese society. Instead of enabling local empowerment, the internationals simply outsourced power and norms to the local elite, whose interests were eventually preserved in the newly built oppressive social, political, and military structures (Richmond 2015). For example, the UNTAET leadership assumed that its success depended on its relationship with the political elite in Timor-Leste, most especially with Gusmão (Bexley and Nygaard-Christensen 2014). Local involvement was exclusive to the local elite, which led to the exclusion of other local actors in the peacebuilding process. For example, the disenfranchisement of clandestine groups, who were not part of the Fretilindominated transitional government, from the decision-making process and rebuilding of security institutions contributed to the discontent that fueled the 2006 security crisis. This aided Gusmão's strict, military, and top-down style of leadership, which helped him successfully lead the resistance and to hold on even after independence, for which Gusmão has been labelled as a potential despot (ibid.). This kind of oppressive structure preserves the local elite's monopoly on decision-making and undermines the agency of the younger generation in Timor-Leste.

Political hegemony is prone to corruption, which has become a concern in Timor-Leste lately (Guterres 2017). Several studies have raised caution over the government's unnecessary spending of public money and inefficient management and control of infrastructure projects (Shoesmith 2011; Scheiner 2015; NygaardChristensen 2016). For example, the increasing number of high-level corruption cases shows that petroleum revenues ${ }^{7}$ have created new opportunities for corruption and administrative malpractice (Bosso 2015, 1). In 2014, Gusmão controversially expelled foreign lawyers and judges from Timor-Leste one day before the trial of then Finance Minister Emilia Pires on corruption charges (Allard 2014). Pires was charged with breaching the law for awarding contracts through a direct award or without a tender to a company owned by her husband (Tempo Semanal 2012). The trial of Pires, including eight other cabinet members, was suspended after Gusmão's decision (Allard 2014). It was a move denounced by foreign governments, international investigators, and the judiciary as Gusmão's strategy to not only protect his ministers from corruption charges, but also to prevent further investigations that might connect to allegations of him carrying out corrupt activities in terms of awarding contracts to family members and friends 
(Holland and March 2009). If these corruption allegations are true, the same political elite is also mismanaging the country's petroleum revenues for their own interests and consequently derailing the country's path towards sustainable economic development. If the government does not combat corruption and increase its institutional capacity to accomplish its planned development projects, these governance issues could undermine what the country has achieved so far in terms of resource management (Sýkora 2013). The government has put measures in place to combat corruption, but if they are not implemented properly, there could be an increased wealth divide in which those who live in poverty will not benefit from the glut of money from petroleum revenues (Asahi 2017, 15).

Since the local that the UN was involved with during the transition was fragmented by differing priorities and interests, their differences spilled over into crucial components of peacebuilding. First, the rebuilding of the security sector was influenced by the animosity between Gusmão and Alkatiri and the loyalty of their supporters. Although it was not the sole reason, this political opposition factored in the outbreak of the crisis. Second, the local leadership was divided over how to deal with calls for justice for crimes committed by Indonesian military officers. Alkatiri and Bishop Carlos Filipe Ximenes Belo supported recommendations for an international tribunal, while Gusmão and Ramos-Horta preferred political reconciliation with Indonesia. The fragmentation within the Timorese leadership built roadblocks against uniting the security forces and delivering justice to the victims of the Indonesian occupation.

Richmond's framework of hybrid peacebuilding (2015), Mac Ginty's hybrid peace variables (2010a; 2011), and Björkdahl and Höglund's categories of responses to frictional encounters (2013) elucidate the events of Timor-Leste's peacebuilding process. The failure to address tensions arising from international/ liberal-local encounters early in the transition contributed to negative hybrid peace in Timor-Leste. The international preference for institution-building and stability remained opposed to the local aspiration for self-governance and national unity. This is one of the reasons why the peacebuilding process in TimorLeste failed to address the tensions arising from international-local encounters. The internationals were successful in building institutions of government, justice, and economy. They were able to quickly export liberal frameworks and values into the newly built institutions. For the Timorese resistance and society in general, the immediate reward of compliance with liberal peace was a referendum to decide the future of Timor-Leste. When stability was at risk, however, such as in pursuing justice from the Indonesian government, they favored strategic adoption of liberal values. The internationals, together with a part of the Timorese leadership, negotiated justice for political reconciliation and stability. The local population, on the other hand, exercised their ability to create alternatives to liberal justice by reverting to traditional mechanisms of justice and reconciliation. The liberal peace assertiveness manifested in institution-building, 
but it faced criticism from the local leadership and society. Initially, there was a growing sense of discontent among the Timorese over not having active roles in the peacebuilding process. They felt that their aspirations for self-governance and national unity were sidelined by international priorities of institutionbuilding and stability. Later in the transition, the local elite was able to adapt or contextualize these liberal institutions based on their interests. The result of this unresolved tension and imbalance from international/liberal-local encounters is a shell of democratic institutions of governance that is essentially dominated by the local elite. This outcome demonstrates that institution-building and local involvement will not be effective unless the dynamics of social conflict are addressed (Jones 2010, 568-569).

\section{Conclusion}

The case of Timor-Leste's post-conflict peacebuilding illustrates the complex dynamics of international-local encounters and illuminates how hybrid peace processes in which the local is embedded in an international peacebuilding process can produce negative consequences. This article examined how negative hybrid peace came about in Timor-Leste and described its characteristics and consequences. Exclusive and superficial local involvement, fragmented local actors, and unresolved tensions from international-local encounters contributed to issues that beset Timor-Leste after the transition. Local involvement was exclusive to the "heroes of resistance," leaving other legitimate groups disenfranchised from the peacebuilding process and thereby contributing to the 2006 security crisis. Even the involvement of the local elite in the Timorization process was superficial at best and without substantive participation. While the approaches employed by international and local actors resulted in the establishment of liberal institutions, they also highlighted the difficulties of delivering the responsibilities of these institutions in a context where the international and local actors were fragmented from within and from each other.

UNTAET's exclusive engagement allowed the local elite to advance their political interests and cement their leadership roles in Timorese society. They were able to maintain power and influence such that the government has remained dominated by the same generation of politicians since the UN missions concluded. This is confirmed by the victory of Francisco Guterres, a Fretilin member and former guerrilla fighter, in the March 2017 presidential election. Only in the recent July 2017 parliamentary elections has this political hegemony started to see challenges from other groups (James 2017; Leach 2017). Applying the concept of negative hybrid peace as an analytical lens reveals that the negative consequences of peacebuilding missions are not solely due to the missteps of the internationals; local actors and agency also share equal responsibility, whether 
they act intentionally or not. Negative hybrid peace is therefore helpful in illuminating the role of local actors and agency in a peacebuilding process and explaining how the conditions of their involvement become a roadblock on a post-conflict society's path to lasting peace.

\section{Acknowledgments}

The author is grateful to the anonymous reviewers for their comments and suggestions. She also wishes to thank Luke Glanville and Joanne Wallis for their academic guidance, and her dissertation examiners for their insights and recommendations. This research would not have been completed without the Australian National University's research scholarship and the Japan Society for the Promotion of Science postdoctoral fellowship.

\section{Notes}

1. Some names of interview participants are withheld at their request.

2. For an overview of the strengths and weaknesses of the local turn in peacebuilding, see Hughes, Öjendal, and Schierenbeck (2015).

3. For a discussion on the scope of activities and extent of the clandestine movement's network, see Braithwaite, Charlesworth, and Soares (2012).

4. Although MAGs' leaders proclaim neutrality, it is widely known that politicians employ them to provide personal security, attend demonstrations, incite violence, and conduct other criminal acts (Pawelz 2015, 124; Timor-Leste Armed Violence Assessment 2009, 3).

5. The author thanks an anonymous reviewer for making this observation.

6. For example, CivPol employed the former chief of police during the Indonesian occupation as a senior police adviser/consultant because he was respected by Timorese communities and was aware of the sentiments of the local population, according to a former UN CivPol officer (personal communication, October 1, 2013).

7. The 610,000-square kilometer Timor Sea is rich in oil and gas reserves. In 2008, the estimated value of oil and gas revenues was around US $\$ 3.2$ billion, which was nine times more than that of Timor-Leste's 2004 non-oil GDP (Lundahl and Sjöholm 2008, 79).

\section{References}

Allard, Tom. 2014. “Exclusive: Timor PM Protecting 'Corrupt' Cabinet Members.” Sydney Morning Herald, November 26. http://www.smh.com.au/world/exclusive-timor-pmprotecting-corrupt-cabinet-members-20141125-11tosz.html (accessed July 29, 2017). Andrieu, Kora. 2010. "Civilizing Peacebuilding: Transitional Justice, Civil Society and the Liberal Paradigm.” Security Dialogue 41 (5): 537-558. 
Asahi, Hideaki. 2017. "A Success Model or an Uneasy Future for Peacebuilding? PostConflict Consolidation of Peace in East Timor." Asian Journal of Peacebuilding 5 (1): $1-20$.

Autesserre, Séverine. 2014. Peaceland: Conflict Resolution and the Everyday Politics of International Intervention. New York: Cambridge University Press.

Barnett, Michael, Songying Fang, and Christoph Zürcher. 2014. "Compromised Peacebuilding." International Studies Quarterly 58 (1): 608-620.

Beauvais, Joel C. 2000-2001. "Benevolent Despotism: A Critique of U.N. State-Building in East Timor." New York University Journal of International Law and Politics 33: 11011178.

Belloni, Roberto. 2012. "Hybrid Peace Governance: Its Emergence and Significance." Global Governance 18 (1): 21-38.

Bexley, Angie, and Maj Nygaard-Christensen. 2014. "From Poet to Despot: the Changing Face of Xanana Gusmao." New Mandala, December 12. http://www.newmandala.org/ from-poet-to-despot-the-changing-face-of-xanana-gusmao/ (accessed September 21, 2017).

Björkdahl, Annika, and Kristine Höglund. 2013. "Precarious Peacebuilding: Friction in Global-Local Encounters.” Peacebuilding 1 (3): 289-299.

Bosso, Francesco. 2015. "Timor-Leste: Overview of Corruption and Anti-Corruption.” Transparency International. http://www.transparency.org/files/content/corruptionqas/ Country_profile_Timor_Leste_2015.pdf (accessed July 29, 2017).

Bowman, Herbert D. 2004. "Letting the Big Fish Get Away: The United Nations Justice Effort in East Timor." Emory International Law Review 18: 371-400.

Braithwaite, John. 2012. "Evaluating the Timor-Leste Peace Operation." Journal of International Peacekeeping 16 (3-4): 282-305.

Braithwaite, John, Hilary Charlesworth, and Adérito Soares. 2012. Networked Governance of Freedom and Tyranny: Peace in Timor-Leste. Canberra: ANU Press.

Chesterman, Simon. 2002. "East Timor in Transition: Self-Determination, State-Building and the United Nations." International Peacekeeping 9 (1): 45-76.

Chopra, Jarat. 2000a. "Introductory Note to UNTAET Regulation 13." International Legal Materials 39 (4): 936-938.

Chopra, Jarat. 2000b. “The UN's Kingdom of East Timor.” Survival 42 (3): 27-39.

Chopra, Jarat. 2002. “Building State Failure in East Timor.” Development and Change 33 (5): 979-1000.

Cooper, Neil, Mandy Turner, and Michael Pugh. 2011. "The End of History and the Last Liberal Peacebuilder: A Reply to Roland Paris." Review of International Studies 37 (4): 1995-2007.

CTF (Commission of Truth and Friendship). 2008. "Final Report of the Commission of Truth and Friendship (CTF) Indonesia-Timor-Leste.” Denpasar. http://cja.org/ downloads/Per-Memoriam-Ad-Spem-Final-Reeport-of-the-Commission-of-Truthand-Friendship-IndonesiaTimor-Leste.pdf (accessed July 29, 2017).

Cummins, Deborah. 2015. Local Governance in Timor-Leste: Lessons in Postcolonial Statebuilding. London and New York: Routledge.

Della-Giacoma, Jim. 2000. “The Next Step: East Timor Deserves Democracy." The Asian Wall Street Journal, June 22.

Doyle, Michael W. 1983. "Kant, Liberal Legacies, and Foreign Affairs." Philosophy \& Public 
Affairs 12 (3): 205-235.

East Timor and Indonesia Action Network. 2005. "ETAN Supports UN Commission's Call for International Involvement in Justice for East Timor." June 28. http://etan.org/ news/2005/06coe.htm (accessed July 29, 2017).

Evans, Christine. 2012. The Right to Reparation in International Law for Victims. New York: Cambridge University Press.

Goldstone, Anthony. 2012. "East Timor." In Exit Strategies and State Building, ed. Richard Capland, 177-196. Cambridge: Oxford University Press.

Guterres, Jonas. 2017. “The Alarming Nature of Corruption in Timor-Leste." The Diplomat, April 7. http://thediplomat.com/2017/04/the-alarming-nature-of-corruption-intimor-leste/ (accessed July 29, 2017).

Heathershaw, John. 2008. "Unpacking the Liberal Peace: The Dividing and Merging of Peacebuilding Discourses." Journal of International Studies 36 (3): 597-621.

Hicks, David. 2009. “'Ema Lorosae', 'Ema Loromonu': Identity and Politics in Timor-Leste.” In East Timor: How to Build a New Nation in Southeast Asia in the 21st Century? (Carnet De L'irasec/Occasional Paper No. 9 - 2009), eds. Christine Cabasset-Semedo and Frédéric Durand, 81-94. Bangkok: Research Institute of Contemporary Souteast Asia.

Hohe, Tanja. 2002. "The Clash of Paradigms: International Administration and Local Political Legitimacy in East Timor." Contemporary Southeast Asia 24 (3): 569-589.

Hohe, Tanja. 2003. "Justice without Judiciary in East Timor." Conflict, Security \& Development 3 (3): 335-357.

Holland, Steve, and Stephanie March. 2009. "Gusmao Faces Corruption Claims." $A B C$ News, June 26. http://www.abc.net.au/news/2009-06-26/gusmao-faces-corruptionclaims/1332630 (accessed July 30, 2017).

Hood, Ludovic. 2006. "Security Sector Reform in East Timor, 1999-2004." International Peacekeeping 13 (1): 60-77.

Human Rights Watch. 2002. “Justice Denied for East Timor: Indonesia’s Sham Prosecutions, the Need to Strengthen the Trial Process in East Timor, and the Imperative of U.N. Action.” December 20. https://www.hrw.org/legacy/backgrounder/asia/timor/ etimor1202bg.htm (accessed July 29, 2017).

Hughes, Caroline. 2009. “'We Just Take What They Offer': Community Empowerment in Post-war Timor-Leste." In New Perspectives on Liberal Peacebuilding, eds. E. Newman, O. P. Richmond, and R. Paris, 218-242. Tokyo: United Nations University Press.

Hughes, Caroline, Joakim Öjendal, and Isabell Schierenbeck. 2015. "The Struggle Versus the Song - the Local Turn in Peacebuilding: An Introduction.” Third World Quarterly 36 (5): 817-824.

Ingram, Sue. 2012. "Building the Wrong Peace: Reviewing the United Nations Transitional Administration in East Timor (UNTAET) through a Political Settlement Lens." Political Science 64 (1): 3-20.

IOM (International Organization for Migration). 2011-2012. “IOM Timor-Leste." https:// www.iom.int/countries/timor-leste/general-information (accessed July 29, 2017).

James, Felicity. 2017. “Timor-Leste Election: 'Disenfranchised Youth' Party Wins First Seats in Parliament.” ABC News, July 23. http://www.abc.net.au/news/2017-07-23/ disenfranchised-youth-party-wins-seats-in-timor-leste-election/8736032 (accessed July 29, 2017). 
Jarstad, Anna K., and Louise Olsson. 2012. "Hybrid Peace Ownership in Afghanistan: International Perspectives of Who Owns What and When." Global Governance 18 (1): 105-119.

Jones, Lee. 2010. “(Post-)Colonial State-Building and State Failure in East Timor: Bringing Social Conflict Back In.” Conflict, Security \& Development 10 (4): 547-575.

Joshi, Madhav, Sung Yong Lee, and Roger Mac Ginty. 2014. "Just How Liberal Is the Liberal Peace?" International Peacekeeping 21 (3): 364-389.

Keohane, Robert. O., and Joseph S. Nye. 1989. Power and Interdependence: World Politics in Transition. Boston: Little, Brown.

Kingma, Kees. 2001. Demobilisation and Reintegration of Ex-Combatants in Post-War and Transition Countries: Trends and Challenges of External Support. Deutsche Gesellschaft für Technische Zusammenarbeit (GTZ) GmbH; Bonn International Center for Conversion. https://www.bicc.de/uploads/tx_bicctools/demobilisation.pdf (accessed July 29, 2017).

Leach, Michael. 2017. "Timor-Leste Elections Suggest Reframed Cross-Party Government." The Interpreter, July 24. https://www.lowyinstitute.org/the-interpreter/timor-lesteelections-suggest-reframed-cross-party-government (accessed July 26, 2017).

Lemay-Hébert, Nicolas. 2009a. "Statebuilding without Nation-Building? Legitimacy, State Failure and the Limits of the Institutionalist Approach." Journal of Intervention and Statebuilding 3 (1): 21-45.

Lemay-Hébert, Nicolas. 2009b. "UNPOL and Police Reform in Timor-Leste: Accomplishments and Setbacks." International Peacekeeping 16 (3): 393-406.

Lemay-Hébert, Nicolas. 2011. "The Bifurcation of the Two Worlds: Assessing the Gap Between Internationals and Locals in State-building Processes." Third World Quarterly 32 (10): 1823-1841.

Lidén, Kristoffer. 2009. "Building Peace between Global and Local Politics: The Cosmopolitical Ethics of Liberal Peacebuilding." International Peacekeeping 16 (5): 616-634.

Lundahl, Mats, and Fredrik Sjöholm. 2008. "The Oil Resources of Timor-Leste: Curse or Blessing?” The Pacific Review 21 (1): 67-86.

Mac Ginty, Roger. 2008. "Indigenous Peace-Making Versus the Liberal Peace." Cooperation and Conflict 43 (2): 139-163.

Mac Ginty, Roger. 2010a. "Hybrid Peace: The Interaction between Top-Down and Bottomup Peace." Security Dialogue 41 (4): 391-412.

Mac Ginty, Roger. 2010b. “No War, No Peace: Why So Many Peace Processes Fail to Deliver Peace." International Politics 47 (2): 145-162.

Mac Ginty, Roger. 2011. International Peacebuilding and Local Resistance: Hybrid Forms of Peace. New York: Palgrave Macmillan.

Mac Ginty, Roger. 2015. "Where Is the Local? Critical Localism and Peacebuilding." Third World Quarterly 36 (5): 840-856.

Mac Ginty, Roger, and Oliver P. Richmond. 2015. "The Fallacy of Constructing Hybrid Political Orders: A Reappraisal of the Hybrid Turn in Peacebuilding." International Peacekeeping 23 (2): 219-239.

Martin, Ian, and Alexander Mayer-Rieckh. 2005. "The United Nations and East Timor: From Self-Determination to State-Building.” International Peacekeeping 12 (1): 125145.

Mc Carthy, John. 2002. "Falintil Reinsertion Assistant Program (FRAP): Final Evaluation 
Report.” International Organization for Migration, June. http://siteresources. worldbank.org/INTCPR/946734-1115629527393/20482576/TimorLesteFRAP.pdf (accessed July 30, 2017).

Millar, Gearoid. 2014. "Disaggregating Hybridity: Why Hybrid Institutions Do Not Produce Predictable Experiences of Peace." Journal of Peace Research 51 (4): 501-514.

Mitchell, Audra. 2010. "Peace Beyond Process?" Millenium-Journal of International Studies 38 (3): 641-664.

Murdoch, Lindsay. 2000. "Peace Stirs a New Nation to Work Towards a Prosperous Future." Sydney Morning Herald, August 26. https://etan.org/et2000c/august/20-26/26peace. htm (accessed July 26, 2017).

Nadarajah, Suthaharan, and David Rampton. 2015. "The Limits of Hybridity and the Crisis of Liberal Peace." Review of International Studies 41 (1): 49-72.

Newman, Edward, Roland Paris, and Oliver P. Richmond, eds. 2009. New Perspectives on Liberal Peacebuilding. Tokyo: United Nations University Press.

Niner, Sarah. 2001. "A Long Journey of Resistance: The Origins and Struggle of CNRT." In Bitter Flowers, Sweet Flowers: East Timor, Indonesia, and the World Community, eds. R. Tanter, M. Selden, and S. R. Shalom, 15-30. Sydney: Pluto Press.

Niner, Sarah. 2004. "Guerilla to President: Xanana Gusmão." Eureka Street, May 22. https://www.eurekastreet.com.au/article.aspx?aeid=835\#.WcMrcYyCyUk (accessed September 21, 2017).

Nixon, Rod. 2012. Justice and Governance: Indigenous Approaches and the 'New Subsistence State.' New York: Routledge.

Norling, Torgeir. 1999. "Past, Present, Future: East Timor's Leader Speaks Out." Taipei Times, November 13. http://www.taipeitimes.com/News/front/archives/1999/11/13/ 0000010495 (accessed July 30, 2017).

Nygaard-Christensen, Maj. 2016. “Timor-Leste in 2015: Petro-Politics or Sustainable Growth." Southeast Asian Affairs 2016: 345-359.

Paris, Roland. 2010. "Saving Liberal Peacebuilding." Review of International Studies 36 (2): 337-365.

Pawelz, Janina. 2015. "Security, Violence, and Outlawed Martial Arts Groups in TimorLeste," Asian Journal of Peacebuilding 3 (1): 121-136.

Perry, Robin. 2009. "The Commission of Truth and Friendship and Justice for East Timor." Alternative Law Journal 34 (3): 199-200.

Philipsen, Lise. 2014. "When Liberal Peacebuilding Fails: Paradoxes of Implementing Ownership and Accountability in the Integrated Approach." Journal of Intervention and Statebuilding 8 (1): 42-67.

Pushkina, Darya, and Philip Maier. 2012. "United Nations Peacekeeping in Timor-Leste." Civil Wars 14 (3): 324-343.

Raeymaekers, Timothy. 2013. "Post-War Conflict and the Market for Protection: The Challenges to Congo's Hybrid Peace." International Peacekeeping 20 (5): 600-617.

Ramos-Horta, Jose. 1999. “East Timor Beyond the Ballot." Kasarinlan 14 (3): 115-130.

Randazzo, Elisa. 2016. “The Paradoxes of the 'Everyday': Scrutinising the Local Turn in Peacebuilding.” Third World Quarterly 37 (8): 1351-1370.

Rees, Edward. 2004. "Working Paper No. 139: Under Pressure: Falintil-Forcas De Defesa De Timor Leste: Three Decades of Defence Force Development in Timor-Leste." Geneva Centre for Democratic Control of Armed Forces (DCAF), April. https://www. 
ciaonet.org/attachments/9549/uploads (accessed July 30, 3017).

Richmond, Oliver P. 2006. “The Problem of Peace: Understanding the 'Liberal Peace.” Conflict, Security \& Development 6 (3): 291-314.

Richmond, Oliver P. 2009. "A Post-Liberal Peace: Eirenism and the Everyday." Review of International Studies 35 (3): 557-580.

Richmond, Oliver P. 2010. “Resistance and the Post-Liberal Peace." Journal of International Studies 38 (3): 665-692.

Richmond, Oliver P. 2011a. A Post-Liberal Peace. London and New York: Routledge.

Richmond, Oliver P. 2011b. "De-romanticising the Local, De-mystifying the International: Hybridity in Timor Leste and the Solomon Islands." Pacific Review 24 (1): 115-136.

Richmond, Oliver P. 2012. "Beyond Local Ownership in the Architecture of International Peacebuilding." Ethnopolitics 11 (4): 354-375.

Richmond, Oliver P. 2015. “The Dilemmas of a Hybrid Peace: Negative or Positive?" Cooperation and Conflict 50 (1): 50-68.

Richmond, Oliver P., and Jason Franks. 2008. "Liberal Peacebuilding in Timor Leste: The Emperor's New Clothes?” International Peacekeeping 15 (2): 185-200.

Richmond, Oliver P., and Jason Franks. 2009. Liberal Peace Transitions: Between Statebuilding and Peacebuilding. Edinburgh: Edinburgh University Press.

Russett, Bruce, ed. 1996. The Fact of Democratic Peace. New Jersey: Princeton University.

Scambary, James. 2009. "Anatomy of a Conflict: The 2006-2007 Communal Violence in East Timor." Conflict, Security \& Development 9 (2): 265-288.

Scheiner, Charles. 2015. "Can the Petroleum Fund Exorcise the Resource Curse from Timor-Leste?” In A New Era? Timor-Leste after the UN, eds. S. Ingram, L. Kent, and A. McWilliam, 73-101. Acton, ACT: Australian National University Press.

Selby, Jan. 2013. “The Myth of Liberal Peacebuilding." Conflict, Security \& Development 13 (1): 57-86.

Shoesmith, Dennis. 2003. "Divided Leadership in a Semi-Presidential System." Asian Survey 43 (2): 231-252.

Shoesmith, Dennis. 2011. “Timor-Leste: On the Road to Peace and Prosperity?” Southeast Asian Affairs. 321-335.

Simangan, Dahlia. 2017. “The Pitfalls of Local Involvement: Justice and Reconciliation in Cambodia, Kosovo and Timor-Leste." Peacebuilding 5 (3): 305-319.

Simonsen, Sven Gunnar. 2009. “The Role of East Timor's Security Institutions in National Integration - and Disintegration.” Pacific Review 22 (5): 575-596.

Smith, Michael G., and Moreen Dee. 2003. Peacekeeping in East Timor: The Path to Independence. Boulder, CO: Lynne Rienner Publishers.

Stanley, Elizabeth. 2009. Torture, Truth and Justice: The Case of Timor-Leste. Oxon and New York: Routledge.

Strating, Rebecca. 2016. Social Democracy in East Timor. Oxon and New York: Routledge.

Suhrke, Astri. 2001. "Peacekeepers as Nation-Builders: Dilemmas of the UN in East Timor." International Peacekeeping 8 (4): 1-20.

Sukma, Rizal. 2002. "Securing East Timor: Military and External Relations." In Peacebuilding and Statebuilding in East Timor, eds. Hadi Soesastro and Landry Haryo Subianto, 85-104. Jakarta: Centre for Strategic and International Studies.

Sýkora, Jiř́. 2013. “Oil in Timor-Leste: A Ticket to Prosperity?” Acta Oeconomica Pragensia 21 (3): 68-85. 
Tempo Semanal. 2012. "Minister of Finance Emilia Pires Approves Budget for Her Husband." November 27. http://temposemanaltimor.blogspot.com/2012/11/ministerof-finance-emilia-pires.html (accessed July 30, 2017).

Timor-Leste Armed Violence Assessment. 2009. "Groups, Gangs, and Armed Violece in Timor-Leste.” Issue Brief Number 2, April. http://www.smallarmssurvey.org/ fileadmin/docs/K-Timor-leste-ava/SAS-Timor-Leste-AVA-IB2-ENG.pdf (accessed November 13, 2017).

Timor-Leste National Alliance for International Tribunal. 2008. "An Open Letter in Response to the CTF Report: 'We Have the Truth, Now We Need Justice." July 15. https://www.laohamutuk.org/Justice/TFC/ANTIonCTFEn.pdf (accessed November 13, 2017).

UN (United Nations) Independent Special Commission of Inquiry for Timor-Leste. 2006. "Report of the United Nations Independent Special Commission of Inquiry for Timor-Leste." Geneva, October 2. http://www.ohchr.org/Documents/Countries/ COITimorLeste.pdf (accessed July 30, 2017).

UN (United Nations). 1992. "An Agenda for Peace: Preventive Diplomacy, Peacemaking and Peace-Keeping." A/47/277, June 17.

UNSC (United Nations Security Council). 1999. "Resolution 1272.” S/RES/1272, October 25.

UNSC (United Nations Security Council). 2002. “Resolution 1410.” S/RES/1410, May 17.

UNSC (United Nations Security Council). 2003. "Resolution 1480.” S/RES/1480, May 19.

UNSC (United Nations Security Council). 2004a. "Resolution 1543." S/RES/1543, May 14.

UNSC (United Nations Security Council). 2004b. "Resolution 1573.” S/RES/1573, November 16.

UNSC (United Nations Security Council). 2005a. "Resolution 1599.” S/RES/1599, April 28.

UNSC (United Nations Security Council). 2005b. "End of Mandate Report of the Secretary-General on the United Nations Mission of Support in East Timor (for the Period from 17 February to 11 May 2005).” S/2005/310, May 12.

UNSC (United Nations Security Council). 2006a. “Resolution 1677.” S/RES/1677, May 12.

UNSC (United Nations Security Council). 2006b. "Resolution 1704.” S/RES/1704, August 25.

UNTAET (United Nations Transitional Administration in East Timor). 1999. "On the Establishment of a National Consultative Council.” UNTAET/REG/1999/2. December 2.

UNTAET (United Nations Transitional Administration in East Timor). 2000a. "On the Establishment of Village and Sub-district Development Councils for the Disbursement of Funds for Development Activities." UNTAET/REG/2000/13, March 10.

UNTAET (United Nations Transitional Administration in East Timor). 2000b. "On the Establishment of a National Council." UNTAET/REG/2000/24, July 14.

UNTAET (United Nations Transitional Administration in East Timor). 2001a. "On the Establishment of a Defence Force for East Timor." UNTAET/REG/2001/1, January 31.

UNTAET (United Nations Transitional Administration in East Timor). 2001b. "On the Election of a Constituent Assembly to Prepare a Constitution for an Independent and Democratic East Timor." UNTAET/REG/2001/2, March 16.

UNTAET (United Nations Transitional Administration in East Timor). 2001c. "On the 
Establishment of the East Timor Police Service." UNTAET/REG/2001/22. August 10. Wallis, Joanne. 2012. "A Liberal-Local Hybrid Peace Project in Action? The Increasing Engagement between the Local and Liberal in Timor-Leste." Review of International Studies 38 (4): 735-761.

Wallis, Joanne. 2013. "Victors, Villains and Victims: Capitalizing on Memory in TimorLeste." Ethnopolitics 12 (2): 133-601.

Wallis, Joanne. 2014. Constitution Making During State Building. New York: Cambridge University Press.

Wallis, Joanne, Renee Jeffery, and Lia Kent. 2016. "Political Reconciliation in Timor Leste, Solomon Islands and Bougainville: The Dark Side of Hybridity." Australian Journal of International Affairs 70 (2): 159-178.

Dahlia Simangan recently obtained her Ph.D. from the Australian National University and is a postdoctoral fellow at the Centre for Policy Research, United Nations University in Tokyo. Her research examines post-conflict peacebuilding in Cambodia, Kosovo, and Timor-Leste in the areas of security, justice and reconciliation, and development. She was a visiting scholar of Columbia University's Advanced Consortium on Cooperation, Conflict and Complexity (AC4) from April to July 2015. She is the recipient of the 2015 Dissertation Award from the Academic Council on the United Nations System (ACUNS). 
